\title{
The Effect of Forest Trees Group Cutting on Accumulation, Density and Temperature of Snow (Case Study: Kheiroud Forest Research Station) in Iran
}

\author{
Mahboubeh Mirzahosseini*, Mohsen Mohseni Saravi \\ Faculty of Natural Resource in University of Tehran, Karaj, Iran
}

Copyright $\bigcirc 2018$ by authors, all rights reserved. Authors agree that this article remains permanently open access under the terms of the Creative Commons Attribution License 4.0 International License

\begin{abstract}
The tree cutting in the forests can affect different environmental aspects such as snow accumulation, density and temperature. This phenomenon was investigated in the Caspian Hyrcanian mixed forests (Namkhaneh seris, Kheiroud, Mazandaran province, Iran) from year 2001 up to 2005. A region with tree cutting was compared with region without any cutting (control). For measuring snow accumulation, 10 pickets in each region were installed and snow height was measured every 5 days. For determining the density, sampling was done with $500 \mathrm{~cm}^{3}$ sampler from different snow depths every 5 days. Finally, snow temperature was measured at different depths with thermometer. The results indicate that the average of snow density in cutting region and control region are $0.178 \mathrm{gr} / \mathrm{cm}^{3}$ and $0.151 \mathrm{gr} / \mathrm{cm}^{3}$, respectively and there is not any significant difference between them. Also decreasing in canopy due to tree cutting has a significant relation with snow accumulation and its depth. Also, the average snow height in control region was $13.88 \mathrm{~cm}$ and after cutting increased to $21.15 \mathrm{~cm}$. Snow temperature increasing is significantly related to the decreasing in canopy. Therefore, the average snow temperature in control region is $-3.3^{\circ}$ $\mathrm{C}$, which decreases to $-10.3^{\circ} \mathrm{C}$ by cutting the trees.
\end{abstract}

Keywords Hardwood, Snow Accumulation, Group Cutting, Snow Temperate, Snow Density, Kheyrud Forest

\section{Introduction}

Utilization of forests for different purpose especially wood production has been widely considered for decades and therefore their harvesting effects on environmental condition has been a great concern [1]. As one of the important hydrological parameters in forest is snowing, it seems that trees cutting in forest can affect this hydrological condition, too [10]. Information in this part is very poor in Iran, Therefore it is necessary to study the influence of group cutting on factors such as snow density and depth and temperature. There are different researches in this respect. For example in southern Dakota mountains in the USA, it was found that snow depth was higher in regions without trees which had caused run off after snow melting $[4,5]$.

Forest cutting is a major anthropogenic disturbance that effects on the physical characteristics of snow and impacts on the snow accumulate that are poorly understood over large areas. Using recent annualized forest inventory data, we estimated cutting - related loss of live biomass in the north of Iran [6].

Forest cutting broadly defined here as human activities that remove trees for timber or for converting forestlands into other land uses. Forests in the Iran experience major management activities and disturbance that strongly affect its density, special germ and depth. Also this characteristics that mention above due to forest cutting activities remain highly uncertain in the country. Although the overall annual rate of Iran forest harvest appears fairly stable since the 1980, the estimated snows accumulate in the conterminous Iran range from 60 to as much as 93 in recent decades. In addition, there is a critical data gap on the characterization of partial cutting in the Iran. Unlike estimates from ecosystem models and remote sensing techniques that usually mix all information together, the inventory- based estimates represent the full range of forest types, age classes, climate zones and management regimes. Therefore, the dataset can isolate different type of disturbances. Here, we present bottom- up estimates of the average annual density, depth, Wight snow. There was $1,942,353$ ha of forests in the northern Iran averaged from 1995-2015[8].

Also Koivusalo \& Kekkonen (2002), in the southern forest of Finland, could determine the snow melting with snow temperature [8].

George et al. (2007) indicated that the topographic and plant coverage had inverse effect on snow accumulation and it's melting [6].

Sobota (2011) has investigated the snow accumulation, 
melting and its surface temperature in northern west of Poland from year 2002 to 2011. Results showed that the snow temperature in higher depth is more to some extent in comparison with snow surface [9]. Considering the previous investigations, It seems that there is a serious lack of data about the influence of group cutting in north Caspian forests of Iran on the snow depth, density and temperate.

\section{Materials \& Methods}

\section{Case Study}

Case study was placed in Caspian Hyrcanian mixed forests (Namkhaneh seris (part of parcel 218), Kheiroud ( $7 \mathrm{~km}$ far from Nowshahr), Mazandaran province, Iran). Area of studied region was $4100 \mathrm{~m}^{2}$ (Figure 1). In fact, the area of each par (cutting area and control was about 2100 $\mathrm{m}^{2}$. This considered parcel has between 11801260 mete heights from Caspian Sea level [23]. Average parcel slope is about $20-30 \%$ and the slop is SW [1]. Considering Nowshahr climatology, its precipitation gradient is about $1300 \mathrm{~mm}$ in June up to $1410 \mathrm{~mm}$ in October. The maximum and minimum temperature of region is about 29 and 2.6 centigrade degree.

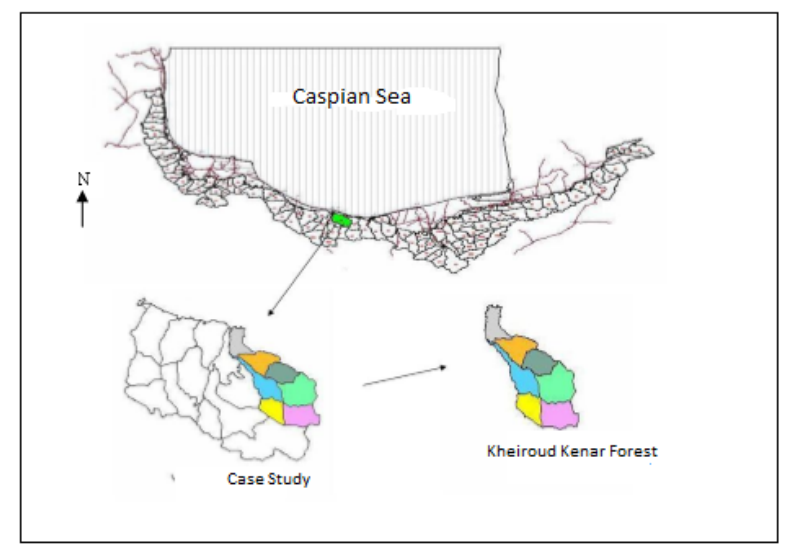

Figure 1. The map of case study

The main parts of soils in case study are soils made by erosion of calcareous stones [14]. It should be mentioned that in Kheiroud kenar region [13], four main soil category of soil can be observed as following: contain of Entisols, Inseptisols, Vertisols and Alfisols [27, 20].

\section{Method}

For measuring the snow depth during 4 years (from 2002 up to 2005), according to area, topographic and slop of region, each $200 \mathrm{~m}^{2}$, one picket was set which totally
10 pickets were considered for cutting part and 10 pickets for control part. Snow depth measuring was measured in both cutting and control parts. Simultaneous with snow depth measuring, snow density was estimated by profile digging with special $500 \mathrm{~cm}^{3}$ sampler in different depth (sampling each $10 \mathrm{~cm}$ from the snow surface up to surface of forest land) [3]. Snow collected in sampler was weighted and considering the specified volume of sample and also the ratio of weight to volume, the snow density was calculated. Moreover, the temperature of snow was determined by thermometer in different depth every 5 days. These measurements continued 4 years. After collecting the data, their normality was tested and then the t-test was considered for comparing between tree cutting and control parts. It should be mentioned that SPSS software was used of statistical analysis [21, 22].

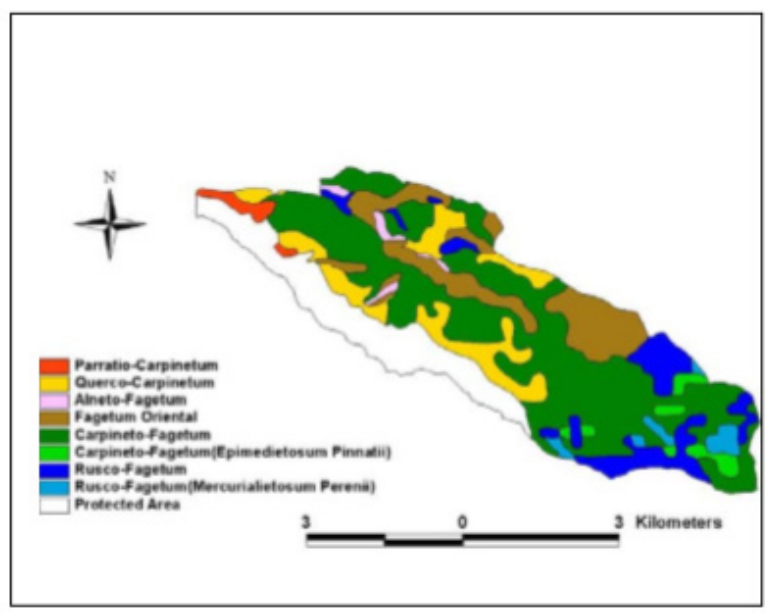

Figure 2. Plants distribution map in case study [2]

\section{Results and Discussion}

$\mathrm{T}$ standard test was done for comparison snow accumulation and density in cutting and control part in winter season and at first of spring season. Results show that in the considered properties, both in the snow accumulation and snow temperature, there is significant different at 95\% confidence level between cutting and control part in deferent years, but in contrast, in snow density, there is no significant different between cutting and control part.

In table 1, brief of variance analysis snow depth and density and temperature in cat and control region [25]

Also Table 2 show number average measurement parameters in deferent years. Curve of snow accumulate depth between cut and control region was brought in figures 3 to 6 . Also Result of comparison snow density in cut and control was brought in 7 to 10 figure and figures of 9 to 12 , show curve of snow temperature in deferent depth and in 4 years. 

of Snow (Case Study: Kheiroud Forest Research Station) in Iran

Table1. Density average, depth and snow temperature in years 2002 up to 2005

\begin{tabular}{|c|c|c|c|c|c|c|c|c|c|c|c|c|}
\hline \multirow{2}{*}{$\begin{array}{c}\text { Treatment } \\
\text { Adjective }\end{array}$} & \multicolumn{4}{|c|}{ Control region } & \multicolumn{4}{c|}{ Cut region } & \multicolumn{4}{c|}{ P value } \\
\cline { 2 - 13 }$y$ & 2002 & 2003 & 2004 & 2005 & 2002 & 2003 & 2004 & 2005 & 2002 & 2003 & 2004 & 2005 \\
\hline $\begin{array}{c}\text { Density }\left(\mathrm{gr} / \mathrm{cm}^{3}\right) \\
*\end{array}$ & 0.163 & 0.094 & 0.163 & 0.2117 & 0.159 & 0.089 & 0.254 & 0.213 & 0.9603 & 0.9432 & 0.9432 & 0.9432 \\
\hline Depth(cm) $)^{*}$ & 7.52 & 11.19 & 19.68 & 16.45 & 12.37 & 16.55 & 32.56 & 23.13 & 0.0497 & 0.0428 & 0.355 & 0.0445 \\
\hline $\begin{array}{c}\text { Temperature(c) } \\
*\end{array}$ & -2.6 & -3.7 & -4.4 & -2.8 & -10.6 & -9.5 & -11.4 & -8.6 & 0.0322 & 0.0411 & 0.0411 & 0.0461 \\
\hline
\end{tabular}

*: significant deferent between cut and control region in $\mathrm{P}$ value $5 \%$ and ns: do not significant deferent

Table 2. Density average, depth and temperature in years from 2002 up to 2005

\begin{tabular}{|c|c|c|}
\hline $\begin{array}{c}\text { Treatment } \\
\text { Adjective }\end{array}$ & Control region & Cut region \\
\hline Density $\left(\mathrm{gr} / \mathrm{cm}^{3}\right)$ & 0.151 & 0.178 \\
\hline Depth $(\mathrm{cm})$ & 13.88 & 21.15 \\
\hline Temperature $\left(\mathrm{c}^{\circ}\right)$ & -3.3 & -10.3 \\
\hline
\end{tabular}

Figure 3 comparison snow dept show in cut and control region after cutting in 2002. This graph is between Jan up to Mars 2002, snow depth after cutting has increased, because tree was cutter and haven't any tree in cut region and therefore can't accept snow in its branch.

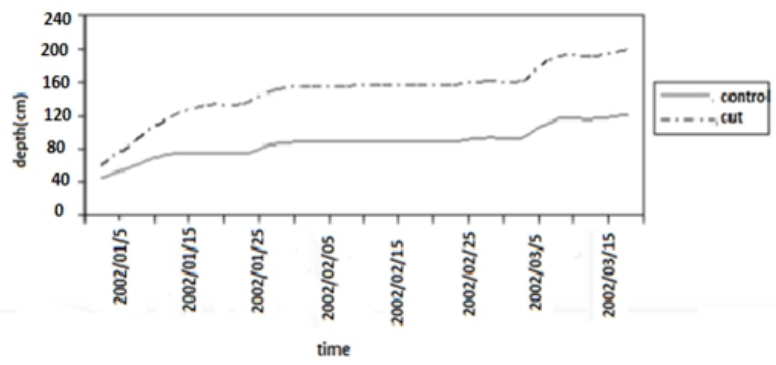

Figure 3. Comparison snow depth in cut and control region after cut in 2002

Figure 4 comparison snow depth show in cut and control region after cutting in 2002. This graph is between Jan up to Mars 2003, snow depth after cutting has increased, because tree was cute and haven't any tree in cut region and therefore can't accept snow in its branch.

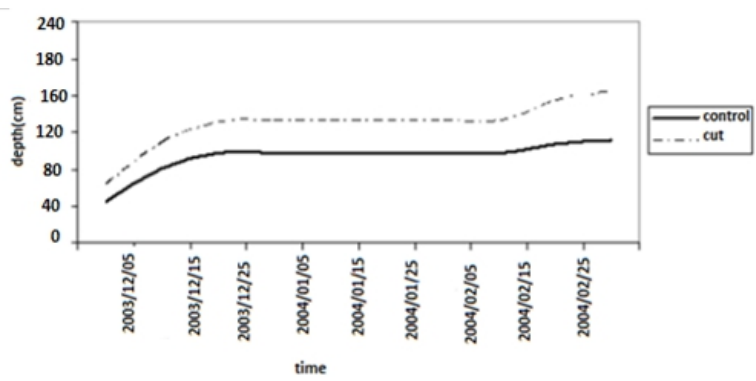

Figure 4. Comparison snow depth in both region after cutting in 2003

Figure 5 comparison snow depth shows in cut and control region after cutting in 2002. This graph is between Jan up to Mars 2004, snow depth after cutting has increased, because tree was cute and haven't any tree in cut region and therefore can't accept snow in its branch.

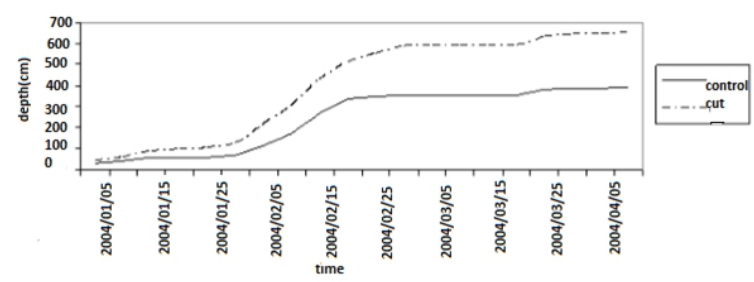

Figure 5. Comparison snow depth both of region after cutting in 2004

Figure 6 comparison snow depth shows in cut and control region after cutting in 2002. This graph is between Jan up to Mars 2005, snow depth after cutting has increased, because tree was cute and haven't any tree in cut region and therefore can't accept snow in its branch.

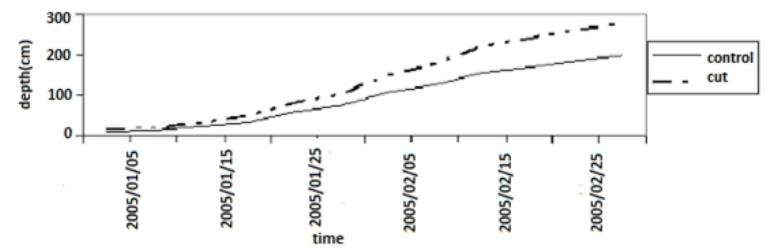

Fiure 6. Comparison snow depth in both region after cutting in 2005

Figure 7 comparison snow density show in cut and control region after cutting in 2002. this graph is between Jan up to Mars 2002, snow density after cutting approximately has increased, because trees was cute and snow accumulated in cut region and therefore density has increased.

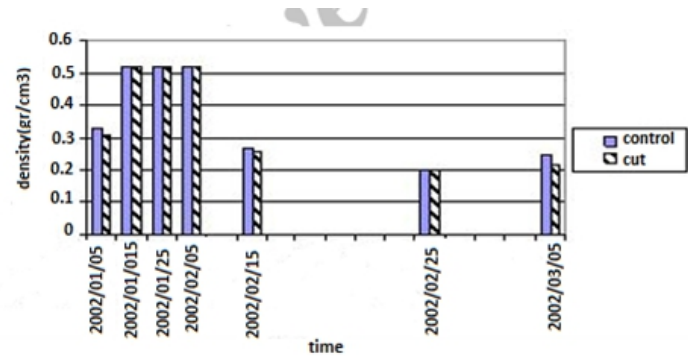

Figure 7. Comparison snow density in both regions after cutting in 2002

Figure 8 comparison snow density show in cut and control region after cutting in 2002. this graph is between 
Jan up to Mars 2003, snow density after cutting approximately has increased, because trees was cut and snow accumulated in cut region and therefore density has increased.

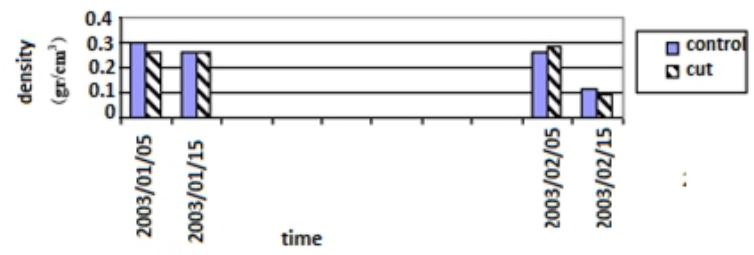

Figure 8. Comparison snow density in both region after cutting in 2003

Figure 9 comparison snow density show in cut and control region after cutting in 2002. this graph is between Jan up to Mars 2004, snow density after cutting approximately has increased, because trees was cut and snow accumulated in cut region and therefore density has increased.

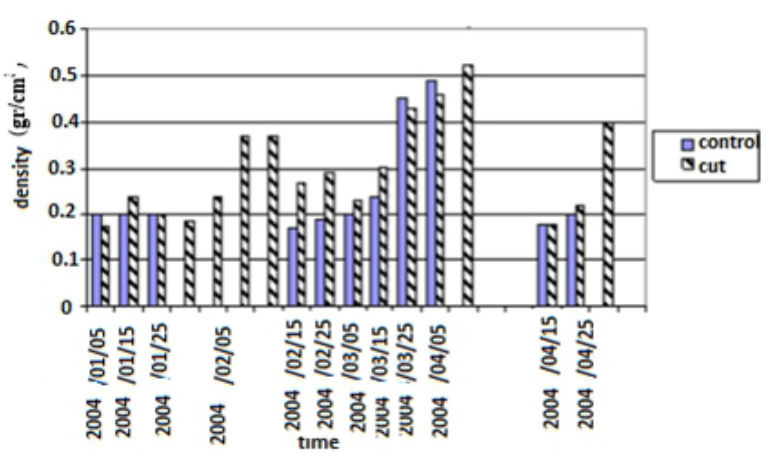

Figure 9. Comparison snow density in both region after cutting in 2004

Figure 10 comparison snow density show in cut and control region after cutting in 2002. this graph is between Jan up to Mars 2005, snow density after cutting approximately has increased, because trees was cut and snow accumulated in cut region and therefore density has increased.

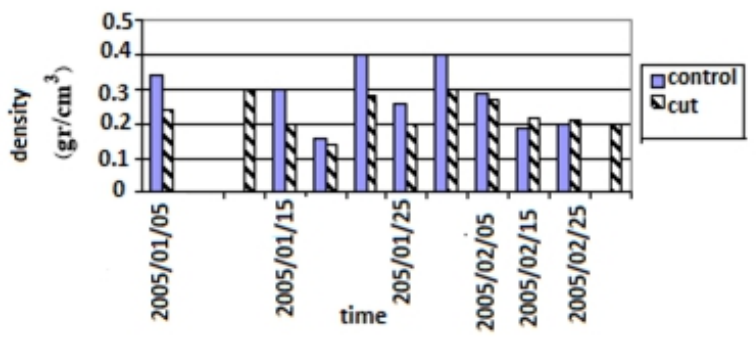

Figure 10. Comparison snow density in both region after cutting in 2005

Figure 11 show the graph of snow temperature average in snow different depths between Jan to Mar 2002. This graph show that temperature in cutting region is cooler than from temperature in control region. Because in cut region, snow has accumulated and therefore temperature is decreased from surface of land to snow depth.

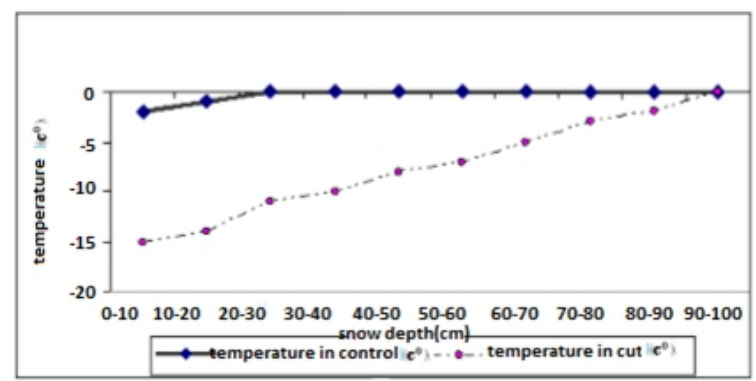

Figure 11. Curve of snow temperature average in different depth in 2002

Figure 12 show the graph of snow temperature average in snow different depths between Jan to Mar 2003. This graph show that temperature in cutting region is cooler than from temperature in control region. Because in cut region, snow has accumulated and therefore temperature is decreased from surface of land to snow depth.

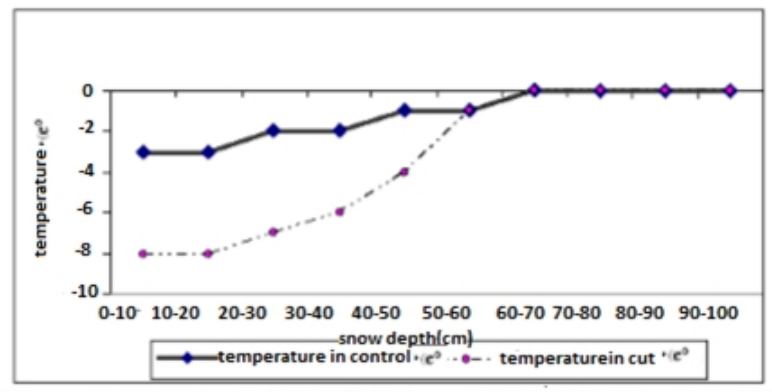

Figure 12. Curve of snow temperature average in different depth in 2003

Figure 13 show the graph of snow temperature average in snow different depths between Jan to Mar 2004. This graph show that temperature in cutting region is cooler than from temperature in control region. Because in cut region, snow has accumulated and therefore temperature is decreased from surface of land to snow depth.

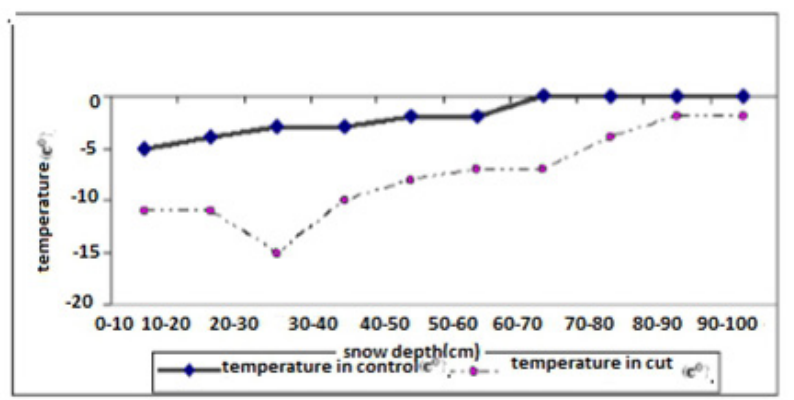

Figure 13. Curve of snow temperature average in different depth in 2004

Figure 14 show the graph of snow temperature average in snow different depths between Jan to Mar 2005. This graph show that temperature in cutting region is cooler 
than from temperature in control region. Because in cut region, snow has accumulated and therefore temperature is decreased from surface of land to snow depth.

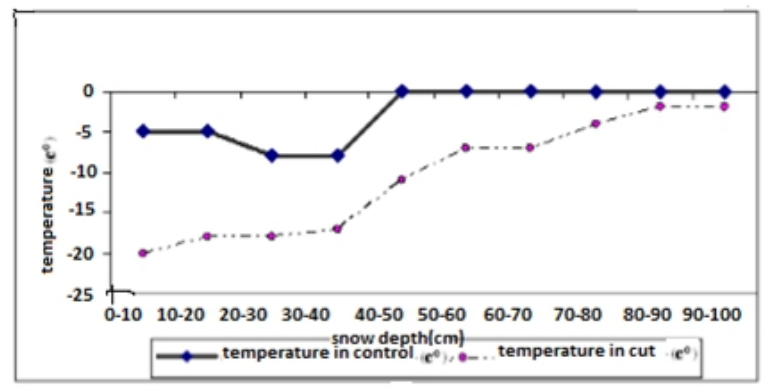

Figure 14. Curve of snow temperature average in different depth in 2005

\section{Discussion}

The most commonly used indicator forest cutting in the Iran is volume removed, which has been tracked by the Office of natural resource in the Mazandaran province, we compared our estimate of the snow volume in two parts of forest [6].

Figures 1 up to 4 show that snow accumulate in cut region during 4 years is more than control region accumulation are rezones below:

1. Omitted of cove caused accumulate snow [17], because foliage and cove, hold some of the snow and caused that place tree less snow accumulate on the grand and also snow on the foliage melt or evaporate steadily, this result is overlap with Bomgartner(1980) that work in mountains of Dakota south. He explains foliage omitted and cannot collected snow and raining on the trees was caused snow accumulated and run off [4] [8].

2. Wind blow is the next caused that wind circulate, caused snow was scattered and accumulations in the place without tree and help to ore accumulate in cute region [18] [24].

3. Snow in cut region accumulated cased wind blow and bring snow from around and cased more accumulated in this region. Georg et al (2007) also investigated that forest cover decline accumulate and snow melt [6] [5]. Investigation snow density alternative state that snow density alternative have been similar in both region and if have been changed, caused temperature differential and melt and freeze. But this deferential was not significant per $\% 5$ in both parts as show in table1. Results variance analysis table in snow temperature in different deep in cut and control parts state that have significant difference in per $\% 5$ between snow deep and snow temperature in all of years [15]. In all if years snow temperature in control region is more and warmer than cut region that cased is trees and cover effect that convey temperate to grand and after accept temperature via snow, snow temperature increase and cased snow melt, this result overlap whit ( Koivusalo \& Kekkonen,2002) researches that woks in Finland south forest in accumulate and snow melt, but have different that they mention what caused snow melt is infrared red that effect direct on the snow melt and this effect sensitive in winter but cover effect don't attention in this way [8]. So figures 9-12 show whit was increase deep both of parts snow temperature increases or warmer that this subject was 2 reason: at first in more deep, snow accept some temperature from ground, second top snows similar to protection and cover was caused increase snow (Thompson, 1999) [28]. Also Yong \& Xiaohua (2008) and Sobota (2011) in similar research find this result that whit increase snow depth increase snow temperature [10] [12]. Finally trees cut can disturb region hydrological balance and event seasonal floods [9] [12].

\section{REFERENCES}

[1] Sarikhani, N. 2001. Forest, University of Tehran prees, $\mathrm{N} 2659,728 \mathrm{p}$.

[2] Majnounian,B. Jourgholami,M. Zobeiri, M. Feghhi,J. Assessment of Forest Harvesting Damage to Residual Stands and Regenerations- a Case Study of Namkhaneh District in Kheyrud Forest. 2009. Environmental science Vol.7 NO.1. p:33-44.

[3] Brokso, K.M., 2003. Hydrology \& management, Iowa. state university Press, 263pp

[4] Bomgartner, M., 1980. Snow accumulation in forest, Dakouta, USA, Forest Ecology \& Management Journal, 235(3): 202-211.

[5] Brofexi, C., 2003. Forest Hydrology, Press McGraw-Hill, New York, 330pp.

[6] Decheng zhou \& et al. 2013. Forest cutting and impacts on carbon in the eastern United States. Scientific reports, 3547(3): 1-7.

[7] Georg g, J., W. Markus, R.G. David \& A. Younes, 2007. The influence of forest and topography on snow accumulation and melt at the watershed-scale, Journal of Hydrology, 347(4): 101-115.

[8] Koivusalo, H. \& T. Kokkonen, 2002. Snow processes in a forest clearing and in a coniferous forest, Journal of Hydrology, 262(1):145-164.

[9] Kristie, J.F., S.H. Terri \& S. Soroosh, 2008. Operational snow modeling:Addressing the challenges of an energy balance model for National Weather Service forecasts, Journal of Hydrology, 360(3): 48-66.

[10] Sobota, I., 2011. Snow accumulation, melt, mass loss, and 
the near- surface ice temperature structure of Irenebreen, Svaldard, Polar Science, 5(3): 327-336.

[11] Scott, W.W., A. Robert, S. Jason \& M. Ward, 2006. Snow accumulation in thinned lodgepole pine stands, Montana, USA, Journal of Forest Ecology and Management, 235(4): 202-211.

[12] Yong, L. \& W. Xiaohua, 2008. The impact of large-scale forest harvesting on hydrology in the willow watershed of central British Colombia, Journal of Hydrology, 359(3): 141-149.

[13] Andrew S.Gregory, Chris W. Watts, Bryan S.Griffiths, Paul D.Hallett.2009, The effect of long- term soil management on the physical \& biological resilience of a range of arable and grassland soils in England. Geoderma journal 153, 172-185.

[14] Bowker, M. A., Belnap, J., Davidson, D. W., Phillips, S. L. 2005: Evidence for micronutrient limitation of biological soil crusts: importance to arid-lands restoration. Ecological Applications, 15: 1941-1951.

[15] Brison, G. and Bates, F. 1998. Climatic and physical factors that influence the homogeneity of regional floods in southeastern Australia, Water Resource Research, v 34, n 12, p 3369- 3381

[16] Smakhtin, D. E. [5] E. Wallance and J. Land. 2001. Geomorphic parameters predict hydrograph characteristics in the southwest. Water resources bulletin. 13(1):217-238.

[17] Fuller, W. E 1914. Flood flows. Trans. Guide lines for determining floods frequency. U.S.Water Resources Council Bulletin press.M.J. 256-617.

[18] Jonathan, C., 2008. Post fire succession in big sagebrush steppe with livestoch grazing. Rangeland Ecology \&
Management, 62(1): 98-110.

[19] K. Croker and M. Zaidman. 2003. Management of water resources and low flow estimation for the Himalayan basins of Nepal. J. of Hydrology, v 282, n 1-4, p 25-35.

[20] Kheirfam, H. Sadeghi, H. Zareii, B. Homaee, M. 2017. Controlling rainfall-induced soil from small experimental plots through inoculation of bacteria and cyanobacteria. Catena 152. 40-45.

[21] Koloskov, P. I 1925. Climatologically Basis of Agriculture in the province of Amur. Blagoveshohesk. 440pp.

[22] Kroll, C. N. and R. M. Vogel. 2002. "Probability Distribution of low stream flow series in the United States." J. of Hydrologic Engrg. ASCE 7(2), 137-146.

[23] Lotan J. E. \& J.K. Brown. 1985. Fires effects on wildlife habitat- Symposium proceedings, March 21,1984, Misoula, Montana, USDA, For.Serv.Gen. Tech. Rep. INT- 186.96p

[24] Lance, T.V. Robert, B.M. Samuel, D.F andL.G. 2004. Patch burning effects on grazing distribution. Journal of Range Management, 57:248-252.

[25] M. ASCE and B. T. Tomas. 1992. Regional flood frequency relation for stream with many years of no flow American Society of civil Engineering's. NewYork., 483-488.

[26] Neff, J.C., Harden, J.W and Gleixner, G., 2005. Fire effects on soil organic matter content, composition and nutrients. NRC Research Prass, 35: 2178-2187.Jafari, M., Sarmadian, F., 2002. Soil basic. University of Tehran press. 456pp.

[27] Thompson, S. A 1999. Hydrology for Water Management, A. A. Balkema Publication, 14. Rotterdam, $362 \mathrm{pp}$. 